\title{
Undervalued Spiny Monkey Orange (Strychnos spinosa Lam.): An Indigenous Fruit for Sustainable Food-Nutrition and Economic Prosperity
}

\author{
Abiodun Olusola Omotayo ${ }^{1, *(1)}$ and Adeyemi Oladapo Aremu $1,2, *$ (D) \\ 1 Food Security and Safety Niche Area, Faculty of Natural and Agricultural Sciences, North-West University, \\ Private Bag X2046, Mmabatho 2745, South Africa \\ 2 Indigenous Knowledge Systems Centre, Faculty of Natural and Agricultural Sciences, North-West University, \\ Private Bag X2046, Mmabatho 2745, South Africa \\ * Correspondence: 25301284@nwu.ac.za (A.O.O.); Oladapo.Aremu@nwu.ac.za (A.O.A.); \\ Tel.: +27-18-389-2573 (A.O.O.)
}

check for updates

Citation: Omotayo, A.O.; Aremu, A.O. Undervalued Spiny Monkey Orange (Strychnos spinosa Lam.): An Indigenous Fruit for Sustainable Food-Nutrition and Economic Prosperity. Plants 2021, 10, 2785. https://doi.org/10.3390/plants10122785

Academic Editor: Ivo Vaz de Oliveira

Received: 19 October 2021

Accepted: 9 December 2021

Published: 16 December 2021

Publisher's Note: MDPI stays neutral with regard to jurisdictional claims in published maps and institutional affiliations.

Copyright: (c) 2021 by the authors. Licensee MDPI, Basel, Switzerland. This article is an open access article distributed under the terms and conditions of the Creative Commons Attribution (CC BY) license (https:// creativecommons.org/licenses/by/ $4.0 /)$.

\begin{abstract}
Strychnos spinosa Lam. is among the top nutrient-dense indigenous fruit species that are predominant in Southern Africa. It is a highly ranked indigenous fruit based on the nutrition and sensorial properties, which make it an important food source for the marginalized rural people. On the basis of the high vitamin C, iron, and zinc content, it has the capacity to improve the foodnutrition and the socioeconomic status of individuals, especially those in the rural areas of the developing nations. The nutritional composition of Strychnos spinosa compare favorably with many of the popular fruits, such as strawberries and orange. Additionally, Strychnos spinosa has antioxidant activity similar to well-known antioxidant fruits, which keeps it in the class of the popular fruits, giving it added nutrition-health-promoting benefits. In order to improve the availability of Strychnos spinosa, more research on the domestication, processing, preservation, value chain, and economic potential need to be further explored. Therefore, we recommend more concerted efforts from relevant stakeholders with interest in Strychnos spinosa fruit production as a possible sustainable solution to food shortage, food-nutrition insecurity, malnutrition, and austerity, mainly in the rural communities of the developing countries.
\end{abstract}

Keywords: fruit tree; food policies; food security; Loganiaceae; nutrients; market economies; novel products

\section{Introduction}

With the declined rate of global undernourishment (15\% within 2000-2004 and 8.9\% in the year 2019), about 690 million individuals remain undernourished globally. Meanwhile, the stunting rate further fell from 33\% of children under age five in 2000 to $21.3 \%$ in 2019 [1-3]. In order to achieve the goal of ending undernutrition by the year 2030, there is need to encourage the consumption of a balanced diet, especially in the rural communities of the developing nations [4-7]. Interestingly, existing literature have ascertained that indigenous fruits are used to cover food lack and shortages, thereby, these remain a key option for dealing with micronutrient shortages during vulnerable times [8,9]. Indigenous fruits have been utilized in several ways since time immemorial for food needs of the local societies [3].

Generally, the potential of many indigenous fruits is underexplored, especially in the area of their basic botany, horticulture, food science, and economic value [10-13]. Indigenous fruits have the potential to provide the necessary phytonutrients required in the diet for food-nutrition security and the income of rural communities where the cultivation of the popular fruit species is not common [14]. In the warmer temperate regions of the globe, an indigenous fruit tree that stands out with a rich source of phytonutrients is the 
Strychnos spinosa [15]. It is one of the most important edible indigenous fruit trees in the wild. The fruit-bearing species of Strychnos belong to the family Loganiaceae. The tree has the capacity to stay edible in tropical heat, which is an important characteristic for food and nutrition security, as this will enhance availability and productivity [16-18].

In traditional medicine, Strychnos spinosa is often used in the treatment of venereal diseases, stomach-related aches, and snake bite attack [19]. Strychnos spinosa is known as a native or introduced species in many African nations. The plant has been reported across different African regions, including Southern Africa, East Africa, and West Africa [20]. In South Africa, Strychnos spinosa grows well in four provinces (Eastern Cape, Limpopo, KwaZulu-Natal, and Mpumalanga).

Furthermore, the conservation status of Strychnos spinosa is categorized as "least concern", as its distribution and abundance possess a low risk of extinction [21,22]. However, the plant has a recent record of declining occurrence in Benin and Burkina Faso (West Africa), which was attributed to factors such as agricultural activities, urbanization, and animal breeding, rather than climate change and its impact [23]. Although the distribution and availability of the Strychnos spinosa is uneven in Africa, its food-nutritional and economic potentials suggest the need for a more conscious and holistic conservation approach.

Strychnos spinosa has several local uses, and it is known to be a rich source of nutrition and phytochemicals, thereby suggesting its potential health benefits [21,24,25]. Given the increasing importance of Strychnos spinosa in food-nutritional sovereignty, as well as its ecological advantage [26-28], this review provides an appraisal on the potential for sustainable food-nutrition and economic prosperity of Strychnos spinosa. It is anticipated that consolidated information on Strychnos spinosa is important in an attempt to unfold its nutritional and economic potential.

\section{Method for Literature Search}

The approach described by Omotayo et al. [29] was employed in literature selection. Different online sources, theses, dissertations, and research reports were explored. We searched online sources such as Web of Science (WOS), Google Scholar, PubMeb, and Scopus, using various terms and phrases. Examples of these include "Strychnos spinosa", "Monkey orange", "nutritional value composition Strychnos spinosa", "ethno-medicinal importance of the Strychnos spinosa", "uses of Strychnos spinosa", and "description of Strychnos spinosa". For this review, the focus of the search was on Africa, southern Africa, and South Africa from the year 1962 to December 2021.

For the search, studies that fit the inclusion criteria were derived in order to explore the content. The five areas explored and categorized were (i) distribution and description of Strychnos spinosa, (ii) uses of Strychnos spinosa, nutritional and phytochemical content (iii) economic potential (iv) postharvest handling, preservation, storage and processing, and (v) domestication of Strychnos spinosa, cultivation problems, and future research direction (Table 1). In this review, a sum of 151 peer-reviewed papers were retrieved that focused on Strychnos spinosa. Finally, an estimated $47.68 \%$ (72) of the literature was relevant, utilized, and included in the review article (Figure 1). 
Table 1. Selection criteria applied for the selection of literature in this review.

\begin{tabular}{|c|c|}
\hline Exclusion & Description \\
\hline Underutilized African fruit plants & Existing studies on different edible and non-edible fruit plants \\
\hline Underutilized southern African fruit plants & $\begin{array}{c}\text { Literature on different edible indigenuos fruits of } \\
\text { southern Africa }\end{array}$ \\
\hline History and horticulture & $\begin{array}{l}\text { Resarch publications on origin, taxonomy, morphology, uses, } \\
\text { domestication, and cultivation of indigenous fruits }\end{array}$ \\
\hline Chemical composition & $\begin{array}{c}\text { Papers on the chemical composition and use of } \\
\text { indigenous fruits }\end{array}$ \\
\hline Non-edible uses & Literature describing uses of indigenous fruits \\
\hline Inclusion & Explanation \\
\hline $\begin{array}{l}\text { Main subject is food nutrition and economic potential of } \\
\text { Strychnos spinosa fruit tree }\end{array}$ & $\begin{array}{c}\text { Nutrition literature, uses, chemicals, and prospects of Strychnos } \\
\text { spinosa }\end{array}$ \\
\hline Description, distribution, and ecology of Strychnos spinosa & $\begin{array}{c}\text { Articles on distribution, taxonomy, morphology, and } \\
\text { distribution of Strychnos spinosa }\end{array}$ \\
\hline Diverse uses of $S$ & Articles documenting the uses of Strychnos spinosa \\
\hline Nutritional and phytochemical content of Strychno & Nutritional, phytochemicals contents of Strychnos spinosa \\
\hline $\begin{array}{l}\text { Postharvest handling, preservation, storage, and processing of } \\
\text { Strychnos spinosa }\end{array}$ & $\begin{array}{c}\text { Articles on postharvest, preservation, and processing of } \\
\text { Strychnos spinosa }\end{array}$ \\
\hline $\begin{array}{l}\text { Challenges, domestication of Strychnos spinosa, cultivation } \\
\text { problems, and way forward }\end{array}$ & $\begin{array}{l}\text { Domestication of Strychnos spinosa. Articles on food value chain, } \\
\text { trade, economic prospects of plants, markets, supply chains, } \\
\text { policy, and interventions. }\end{array}$ \\
\hline
\end{tabular}

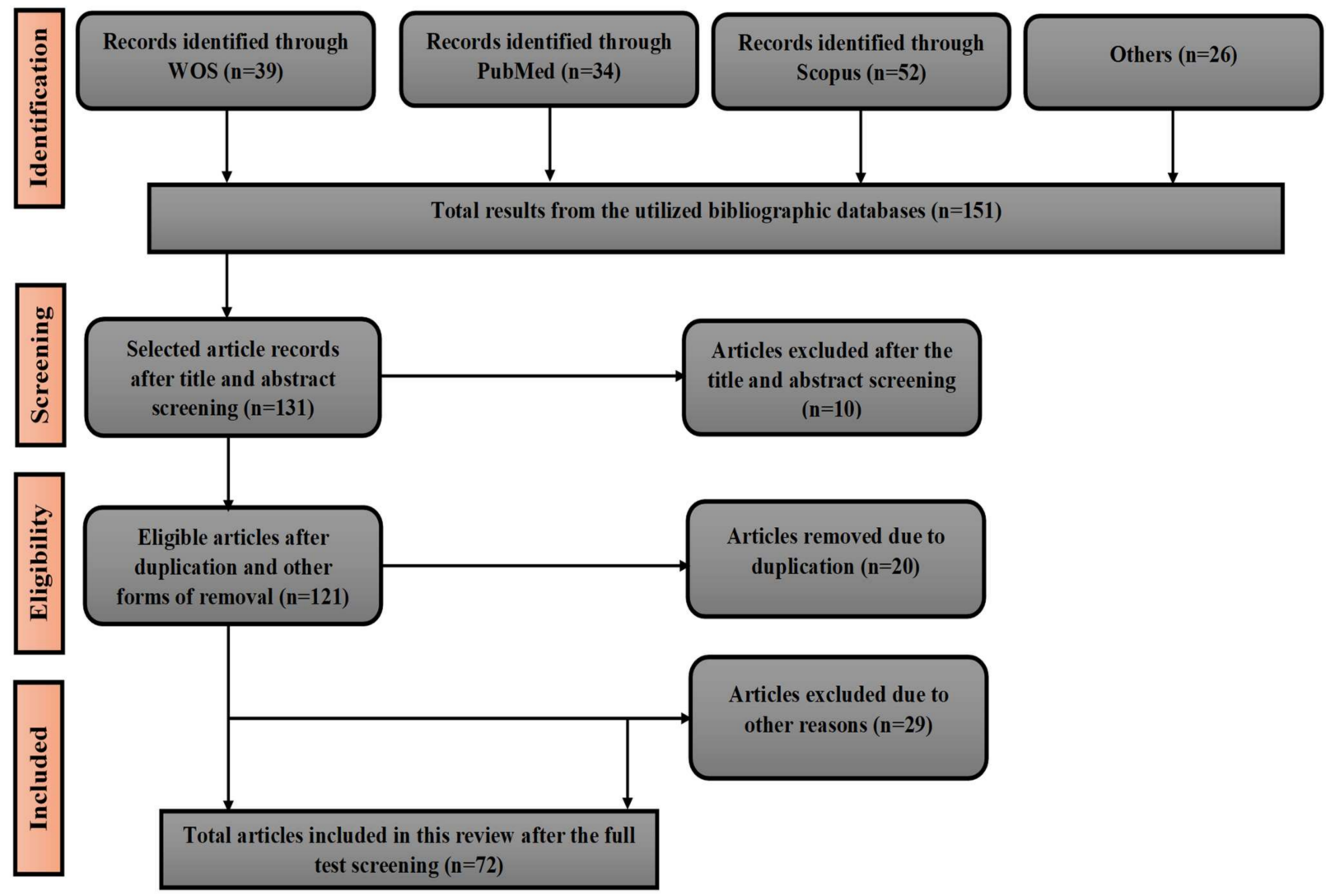

Figure 1. Preferred reporting items for systematic reviews and meta-analyses (PRISMA) for the exclusion and inclusion of articles. 


\section{Botanical Description and Taxonomy of Strychnos spinosa}

About 75 species of Strychnos exist in Africa, with 20 species (e.g., Strychnos innocua, Strychnos cocculoides, Strychnos pungens, and Strychnos spinosa) producing consumable fruits in drought-prone and semi-arid areas [18,30,31]. Strychnos spinosa is a small tree of 1-7 m height, having straight and curved axillary spines, as well as a corky back [32]. The leaves are simple and oval (Figure 2a,b). The fruit is edible, round-shaped, $6-15 \mathrm{~cm}$ in diameter, and resembles a typical orange $[31,33]$. The unripe fruits (Figure $2 b$ ) are green, with wood peel of $34 \mathrm{~mm}$ that becomes yellow (Figure 2c) when ripe [31].

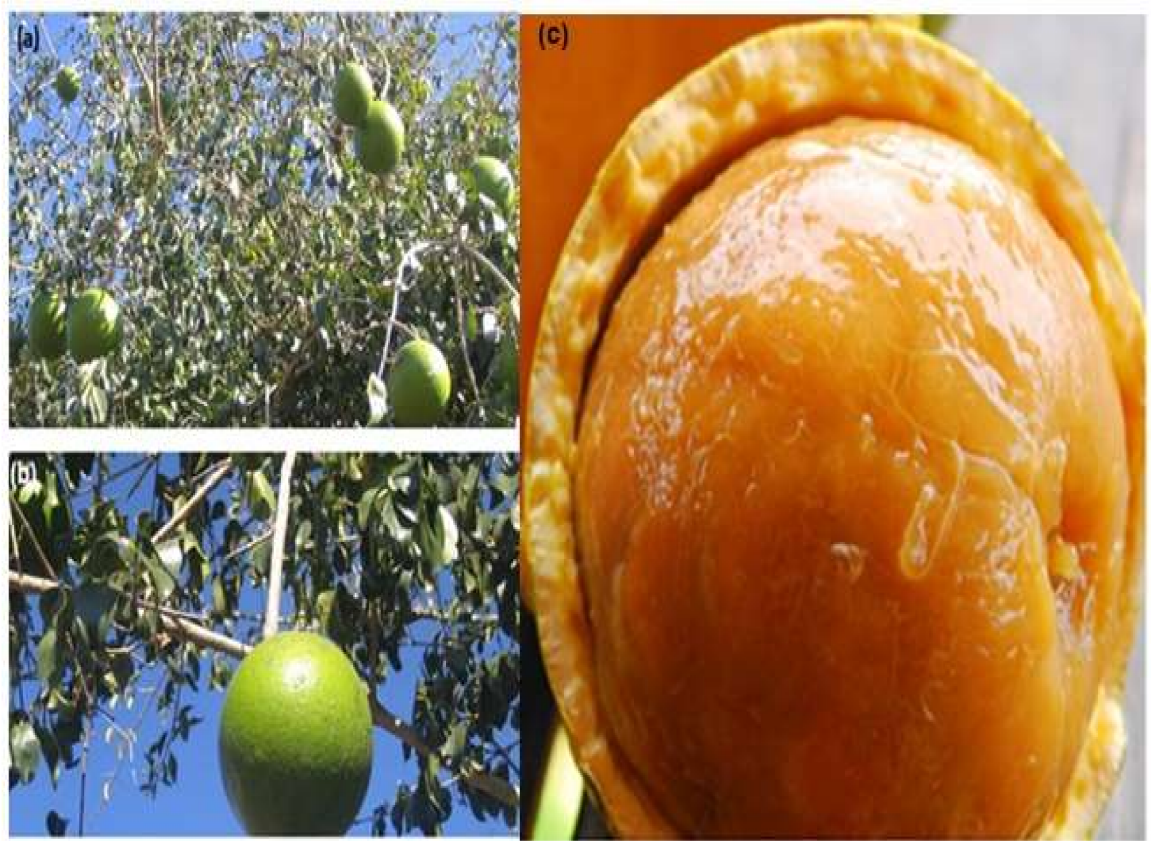

Figure 2. Morphology of Strychnos spinosa. (a) tree at fruiting stage; (b) mature green fruit; (c) ripe fruit.

Strychnos spinosa fruit has a juicy, sweet-sour pulp, which is pale brown, with about a $3 \mathrm{~cm}$ flat seed, slightly similar to apricots [34]. Strychnos spinosa grows in well-drained soils [33,35]. Fruit weighs between 145 and $383 \mathrm{~g}$, while about 300-700 fruits (40-100 kg) can be produced per tree stand. Strychnos spinosa is a seasonal fruit tree that is harvested between August and December [31]. However, the domestication of Strychnos spinosa remains in experimental stages, which is still a problem associated with its commercial prospect. Presently, Strychnos spinosa can be propagated via seeds, grafting, or budding, with the production of fruit starting 3-5 years after planting [27].

\section{Nutritional and Phytochemical Content of Strychnos spinosa \\ 4.1. Nutritional Composition of the Strychnos spinosa}

Strychnos spinosa fruit contain energy, fibers, crude protein, and minerals (Table 2) [18]. Compared to other fruits, the vitamin C content for Strychnos spinosa is similar to that of oranges (Citrus sinensis) $(50 \mathrm{mg} / 100 \mathrm{~g})$ and strawberries (Fragaria ananassa) $(59 \mathrm{mg} / 100 \mathrm{~g})[18,31]$. Therefore, the consumption of Strychnos spinosa provides a source of ascorbate and may alleviate nutrition insecurity for local communities. Most importantly, its fruit pulp (Figure 2c) can be sun-dried as a food preserve, thereby extending shelf-life and availability. 
Table 2. Proximate, vitamin C, and mineral composition of Strychnos spinosa fruit.

\begin{tabular}{cc}
\hline Component & Content Based on Amarteifio and Mosase [36] \\
\hline Dry matter & Proximate and vitamin C composition \\
Ash & $19.7(\%)$ \\
Crude protein & $4.6(\%)$ \\
Fat & $3.3(\%)$ \\
Fibre & na \\
Acid detergent lignin & na \\
Acid detergent fibre & $4.4(\%)$ \\
Neutral detergent fibre & $6.1(\%)$ \\
Total carbohydrate & $6.2(\%)$ \\
Energy value (kJ/100 g) & na \\
Vitamin C & na \\
Total soluble sugar (\%) & $88(\mathrm{mg} / 100 \mathrm{~g})$ \\
Total sugar & na \\
Total acidity & na \\
& na \\
\hline Phosphorus & Mineral composition $(\mathrm{mg} / 100 \mathrm{~g}$ FW) \\
Calcium & 66 \\
Magnesium & 56 \\
Iron & 49 \\
Potassium & 0.11 \\
Sodium & 1370 \\
Zinc & 21.7 \\
Copper & 0.22 \\
Manganese & na \\
\hline na \\
\hline
\end{tabular}

Note: na = not available, FW = fresh weight.

Strychnos spinosa fruit is a good dietary source of carbohydrates and proteins. Furthermore, it contains important minerals, namely iron, zinc, copper, and manganese [37], thereby suggesting that the consumption of Strychnos spinosa may serve as a source to meet the body requirement of zinc, iron, copper, and manganese. The deficiency of microminerals in the human body impairs growth and increases the susceptibility of such individuals to infections and risk of mortality, especially in children [38]. Although the presence of these aforementioned minerals in Strychnos spinosa fruit has been indicated, a wide variability in concentrations for some of them as reported by Lockett, et al. [39].

\subsection{Phytochemicals in Strychnos spinosa}

Phytochemicals are biological active compounds, such as the flavonoids and phenolic acids, with health-promoting values, such as anti-ageing and inflammation $[18,21,40,41]$, which were mainly attributed to their ability to scavenge free radicals $[18,42,43]$. The rich phytochemicals that are abound in different parts of Strychnos spinosa remain key to explaining their food-nutritional benefits and future potential [44-47]. Diverse phytochemicals were confirmed in the leaves, branches, seeds, and fruit pericarp of Strychnos spinosa (Table 3). In addition, significant amount of phenolics and flavonoids were detected in the root-bark $[37,48]$. 
Table 3. Overview of phytochemicals in Strychnos spinosa.

\begin{tabular}{cl}
\hline Plant Part & \multicolumn{1}{c}{ Examples of Phytochemical } \\
\hline Leaves & $\begin{array}{l}\text { Glycosides, tannins, saponins, anthraquinones, steroids, alkaloids, } \\
\text { and terpenoids [24,47,49] } \\
\text { Tannins, flavonoids, terpenoids, saponin, steroids, glycosides, } \\
\text { and phenols [50,51] }\end{array}$ \\
Tranches & $\begin{array}{l}\text { Tannins, saponins, anthraquinones, steroids, alkaloids, glycosides, } \\
\text { and terpenoids [24] }\end{array}$ \\
Stem bark & $\begin{array}{l}\text { Alkaloids, tannins, phenols, phlobatannins, and steroids [52] } \\
\text { Seed }\end{array}$ \\
Fruit pericarp & $\begin{array}{l}\text { Alkaloids, terpenes, sterols, fatty acids, flavonoids, and saponin [53] } \\
\text { phlobatannins, and saponins [37,50] }\end{array}$ \\
Root-bark &
\end{tabular}

\subsection{Physicochemical Properties of Strychnos spinosa}

Strychnos spinosa fruit shows a delicate complex of aroma volatiles that are identified as a mixture of apricot, clove, pineapple, and citrus [26,33]. The degree of Strychnos spinosa ripeness influences the taste and sugar profile that varies based on the environmentalrelated factors [18]. Based on existing studies (Table 4), a wide variation have been confirmed in Strychnos spinosa [18,31]. The presence of organic acids in Strychnos spinosa is explained by the acidic content that blends with sugars, thereby making the plant to exert a blended acid-sweet taste [18]. The partial solubilization of the pectin and cellulose by the plants' enzymes, polygalacturonase [54], pectinmethylesterase, and lyase, during ripening affects the texture and juiciness of the fruit $[18,31]$. The sensory studies reveal that potential exists for product development and commercialization of the plant.

Table 4. Sensory properties in the Strychnos spinosa fruit.

\begin{tabular}{cc}
\hline Properties & Description \\
\hline Taste & Tarty/fermented acid-sweet $[18,24]$ \\
& Major compound $(>75 \%)$ trans-isoeugenol-4.762 mg/g FW [18,24] \\
Aroma volatiles & Other compounds: eugenol-307 $\mu \mathrm{g} / \mathrm{g} \mathrm{FW}$; chavicol-172 $\mu \mathrm{g} / \mathrm{g} \mathrm{FW} ;$ \\
& $\rho$-trans-anol—647.5 $\mu \mathrm{g} / \mathrm{g} \mathrm{FW} ; 123.5 \mu \mathrm{g} / \mathrm{g} \mathrm{FW}[31]$ \\
Aroma & Clove $[41]$ \\
Texture & Not available $[41]$ \\
Color & Yellow $[28,31]$ \\
Acidity & $0.77[41]$ \\
$\mathrm{pH}$ & $2.6-3.33[31]$ \\
& $3.96[18,24]$ \\
\hline
\end{tabular}

\subsection{Antinutritional and Toxicological Properties of Strychnos spinosa}

Antinutritional properties have an adverse effect on the food digestion in the light of the food classes, such as protein and carbohydrates, and decrease the bioavailability of minerals, such as iron and zinc $[49,54,55]$. The reported components of such in Strychnos spinosa were low and below the established toxic level [56,57]. The seeds of Strychnos spinosa contain strychnine and are bitter tasting [31,58]. Toxic alkaloids are present in the seeds and unripe pulp of Strychnos spinosa [58].

\section{Postharvest Handling, Preservation, Storage, and Processing of Strychnos spinosa}

\subsection{Postharvest Handling}

Strychnos spinosa fruits are harvested by shaking, hitting, knocking, or plucking the trees [18]. On the other hand, unripe Strychnos spinosa fruits are harvested and buried under a light sand for months, until it is ripe, in order to prevent postharvest losses [16,26,59]. The fruit pulp usually changes from its dry texture to a golden color after storage and, hence, is ready to be consumed [18]. As applicable with other climacteric fruits, during storage, Strychnos spinosa increase in soluble solid content and accumulate glucose, sucrose, 
and fructose [26]. The slow spoilage attributed to the fruit can be linked to the hard texture that assists in resisting insects and pathogens [16,60-62].

\subsection{Products Preservation}

Strychnos spinosa can be processed to dried products, but the preparation methods and conditions vary across locations in a small-scale level. Postharvest processing of Strychnos spinosa can be achieved through drying, juicing, maceration, and cooking. Although, storage influences the bioavailability and physical characteristics of the plant [63]. In southern Africa, Strychnos spinosa fruits are often dried by fire and or direct sunlight too, and thereafter grinded into flour [18]. Additionally, the sun-dried Strychnos spinosa pulp can be kept for 2 months to 5 years, making heat-drying a good preservation method for the rural communities [64]. The moisture content of Strychnos spinosa fruit ranges from 60 to $91 \%$, which mainly depends on the degree and method of heating $[56,65]$. In addition, a properly dried fruit product does have a residual moisture content that ranges between 18 and $24 \%$, with a good shelf-life $[66,67]$.

\subsection{Advantages and Challenges of Processing Techniques}

Currently, the impact of processing Strychnos spinosa and the assessment of its contribution to nutrient uptake is not well documented. Therefore, optimization of the processing and profiling of the food value of Strychnos spinosa and its products is important for the improvement of the processing procedures, which has the potential to increase the demand for the plant and its products (Figure 3). On this basis, we have identified several advantages, disadvantages, and recommendations for processing Strychnos spinosa. Considering the nutritional quality of the fruit, it may easily serve as an important source of nutrients for children and pregnant women $[17,54,68]$. Thus, improved processing of Strychnos spinosa fruit could be a sustainable solution to the problems of the rural communities [18].

\section{MONKEY ORANGE PROCESSING TECHNIQUES}

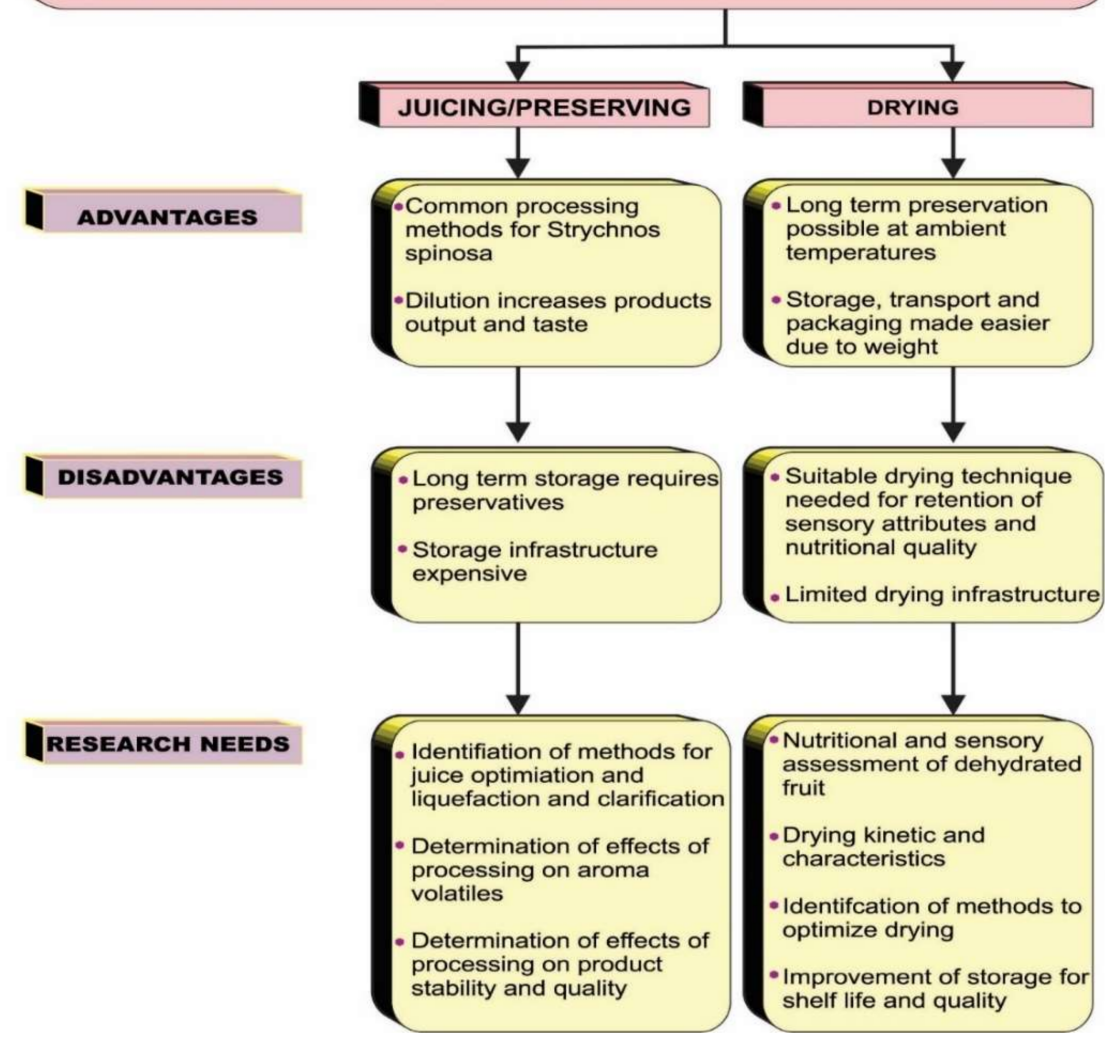

Figure 3. Products, processing, and way forward for Strychnos spinosa. 


\subsection{Nutritional Quality and Economic Potential of Strychnos spinosa}

Strychnos spinosa fruit and its byproducts can contribute to the economy and rural livelihood in Africa. This undervalued plant has potential that can make it withstand market competition with respect to exotic fruits (e.g., orange and strawberry). The high nutritional components and diverse phytochemicals in the plant confer immense benefits. Hence, large-scale production, marketing, and trading of Strychnos spinosa fruit remain important for sustainable livelihood and economic development, especially in the rural communities. Presently, there is paucity of knowledge, with limited literature on the several aspects of the fruit [69]. The commercialization of Strychnos spinosa will remain low until the economic returns on investment associated with the domestication of the fruit tree are profitable [70].

\section{Domestication of Strychnos spinosa, Cultivation Problems, and Way Forward}

Strychnos spinosa has been cultivated in southern Africa but without tangible results [9,71]. To date, no trials of the cultivation of Strychnos spinosa have been conducted in Africa; hence, the fruit tree is mainly sourced from the wild populations. The problems experienced by the rural populations concerning the cultivation of the underutilized fruit as a crop are: (1) land available, (2) slow growth cycle, minimal yield, and (3) common fast-cash economic culture [17,72]. Enhanced and effective information dissemination, including findings and activities, may improve as more stakeholders participate (Figure 4).

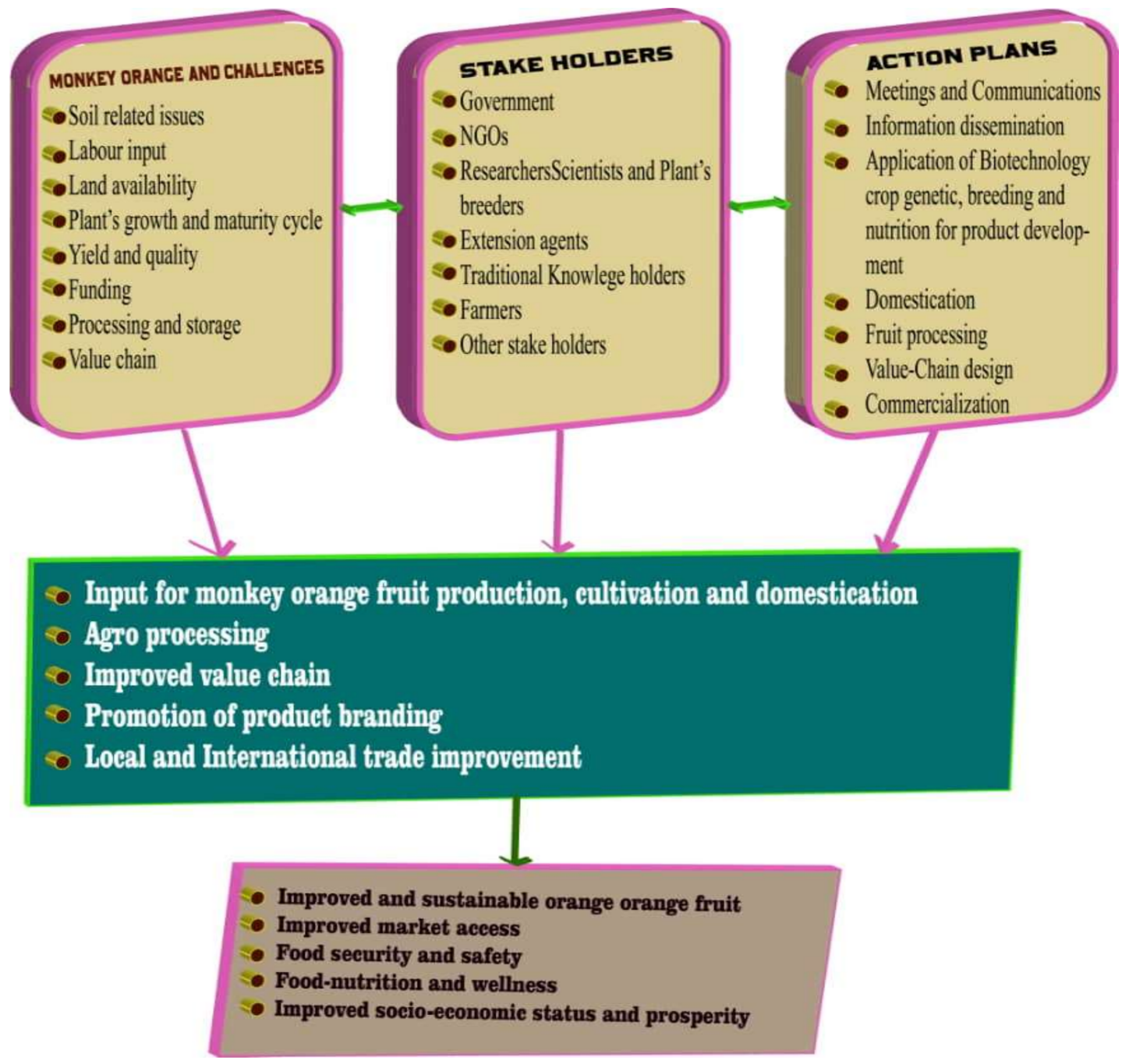

Figure 4. Schematic framework of priority areas for intervention on Strychnos spinosa. 
There is need for active and effective collaborations by the stakeholders on Strychnos spinosa. Research findings on the plants can be disseminated to the rural communities, through local NGOs and other relevant stakeholders, such as the agricultural extension services. Improving processing of Strychnos spinosa can enhance the possibilities for its domestication, agro-processing, production, and commercialization [29]. These envisaged findings will be useful to Strychnos spinosa and the much-needed intervention in research of indigenous fruit trees.

Areas for Further Research

Sensory and nutritional composition of Strychnos spinosa during storage is not available. There is paucity of information on the suitability of the drying methods for Strychnos spinosa. Therefore, further studies on the suitability of dried products and characteristics need to be conducted to establish a drying method that fits local conditions and the possibility for commercialization. Furthermore, few studies have evaluated the nutritional and sensorial characteristics of fresh Strychnos spinosa juice [18]. Therefore, improving the production processes of Strychnos spinosa through preservation technique optimization needs to be investigated. Exploration of the value chain to enhance the economic value and potential of Strychnos spinosa is needed. Finally, research by the plant scientists and breeders on the domestication of Strychnos spinosa needs to be given more priority, owing to its commercial, nutritional, and economic potential.

\section{Conclusions and Recommendations}

Strychnos spinosa fruit have the potential to impart livelihood benefits and improve the nutritional status, as well as the economic prosperity, of the rural population. The micronutrients and macronutrients in the fruit tree are key to its relevance. On this basis, Strychnos spinosa is an important food source for children, pregnant women, and the poor. Nonetheless, limited research has been conducted regarding the value addition and processing for Strychnos spinosa in comparison with many popular and commercial fruits. The plant has great potential in the African rural communities, since the local environmental conditions are appropriate for its cultivation. In order to mitigate some of the existing challenges affecting the domestication of the plant for commercialization, there is need for trans-disciplinary research by different stakeholders, as well as the suggested action plan to improve the problems associated with the cultivation of the plant. Overall, we proposed priority areas for policy and intervention, and recommend an all-inclusive and sustainable development approach, as Strychnos spinosa could contribute to the attainment of the food-nutrition target of the United Nations Sustainable Development Goals (UN SDG, 2030).

Author Contributions: Conceptualization, A.O.O. and A.O.A.; methodology, A.O.O. and A.O.A.; writing—original draft preparation, A.O.O.; writing—review and editing, A.O.A. All authors have read and agreed to the published version of the manuscript.

Funding: Adeyemi Oladapo Aremu received research fund from the National Research Foundation NRF, Incentive Funding for Rated Researchers, Grant UID: 109508. We appreciate the institutional support (including the payment of the APC) from the Food Security and Safety Niche Area, the Faculty of Natural and Agricultural Sciences (FNAS), North-West University, Mmabatho, South Africa.

Acknowledgments: Moloko Mojapelo's (Department of Agriculture, Forestry and Fisheries Directorate Plant Production: Indigenous Food Crops Division) support in providing the photographs of Strychnos spinosa used in this review is appreciated.

Conflicts of Interest: The authors declare no conflict of interest. 


\section{References}

1. Emadi, M.H.; Rahmanian, M. Commentary on Challenges to Taking a Food Systems Approach within the Food and Agriculture Organization (FAO). In Food Security and Land Use Change under Conditions of Climatic Variability; Springer: Cham, Switzerland, 2020; pp. 19-31.

2. Food and Agriculture Organization (FAO); International Fund for Agricultural Development(IFAD); United Nations Children's Fund (UNICEF); World Food Program(WFP); World Health Organization (WHO). The State of Food Security and Nutrition in the World 2020; Food and Agriculture Organization: Rome, Italy, 2020.

3. Gomez, M.I. A Resource Inventory of Indigenous and Traditional Foods in Zimbabwe; University of Zimbabwe Publications: Zambezia, Mozambique, 1989.

4. Omotayo, A.O. Farming households' environment, nutrition and health interplay in Southwest, Nigeria. Int. J. Sci. Res. Agric. Sci. 2016, 3, 84-98. [CrossRef]

5. Omotayo, A.O.; Aremu, B.R.; Alamu, O.P. Food utilization, nutrition, health and farming households' income: A critical review of literature. J. Hum. Ecol. 2016, 56, 171-182. [CrossRef]

6. Omotayo, A.O. Parametric assessment of household's food intake, agricultural practices and health in rural South West, Nigeria. Heliyon 2020, 6, e05433. [CrossRef] [PubMed]

7. Omotoso, A.B.; Daud, A.S.; Adebayo, R.A.; Omotayo, A.O. Socioeconomic determinants of rural households' food crop production in Ogun state, Nigeria. Appl. Ecol. Environ. Res. 2018, 16, 3627-3635. [CrossRef]

8. Laverdiere, M.; Mateke, S. Non-Wood Forest Products: Food for Life. Indigenous Fruit Trees in Southern Africa. Available online: https: / /agris.fao.org/agris-search/search.do?recordID=XF2015045277 (accessed on 22 May 2021).

9. Leakey, R.R.B.; Akinnifesi, F.K. Towards a Domestication Strategy for Indigenous Fruit Trees in the Tropics. In Indigenous Fruit Trees in the Tropics: Domestication, Utilization and Commercialization; CABI: Wallingford, UK, 2008; pp. $28-49$.

10. Van Wyk, B.E. The potential of South African plants in the development of new food and beverage products. S. Afr. J. Bot. 2011, 77, 857-868. [CrossRef]

11. Cemansky, R. Africa's indigenous fruit trees: A blessing in decline. Environ. Health Perspect. 2015, 123, A291-A296. [CrossRef] [PubMed]

12. Richmond, R.; Bowyer, M.; Vuong, Q. Australian native fruits: Potential uses as functional food ingredients. J. Funct. Foods 2019, 62, 103547. [CrossRef]

13. Pfukwa, T.M.; Chikwanha, O.C.; Katiyatiya, C.L.F.; Fawole, O.A.; Manley, M.; Mapiye, C. Southern African indigenous fruits and their byproducts: Prospects as food antioxidants. J. Funct. Foods 2020, 75, 104220. [CrossRef]

14. Omotayo, A.O.; Ndhlovu, P.T.; Tshwene, S.C.; Aremu, A.O. Utilization pattern of indigenous and naturalized plants among some selected rural households of North West province, South Africa. Plants 2020, 9, 953. [CrossRef]

15. Madzimure, J.; Nyahangare, E.T.; Hamudikuwanda, H.; Hove, T.; Belmain, S.R.; Stevenson, P.C.; Mvumi, B.M. Efficacy of Strychnos spinosa (Lam.) and Solanum incanum L. aqueous fruit extracts against cattle ticks. Trop. Anim. Health Prod. 2013, 45, 1341-1347. [CrossRef]

16. Mwamba, C.K. Monkey Orange: Strychnos Cocculoides; Crops for the Future: Southampton, UK, 2006.

17. Omotayo, A.O.; Aremu, A.O. Underutilized African indigenous fruit trees and food-nutrition security: Opportunities, challenges, and prospects. Food Energy Secur. 2020, 9, 220. [CrossRef]

18. Ngadze, R.T.; Linnemann, A.R.; Nyanga, L.K.; Fogliano, V.; Verkerk, R. Local processing and nutritional composition of indigenous fruits: The case of monkey orange (Strychnos spp.) from Southern Africa. Food Rev. Int. 2017, 33, 123-142. [CrossRef]

19. Hedberg, I.; Hedberg, O.; Madat, P.J.; Mshigeni, K.E.; Mshiu, E.; Samuelsson, G. Inventory of plants used in traditional medicine in Tanzania. II. Plants of the families dilleniaceae-Opiliaceae. J. Ethnopharmacol. 1983, 9, 105-127. [CrossRef]

20. Kokwaro, J. Medicinal plants of East Africa. East African Literature Bureau. University of Nairobi Press: Nairobi, Kenya 1976, 45. Available online: http:/ /41.204.161.209/handle/11295/34820 (accessed on 1 December 2021).

21. Aremu, A.O.; Moyo, M. Health Benefits and Biological Activities of Spiny Monkey Orange (Strychnos spinosa Lam.): An African Indigenous Fruit Tree. J. Ethnopharmacol. 2022, 283, 114704. [CrossRef] [PubMed]

22. Anjarwalla, P.; Belmain, S.; Sola, P.; Jamnadass, R.; Stevenson, P.C. Guide des Plantes Pesticides. In Optimisation des Plantes Pesticides: Technologie, Innovation, Sensibilisation et Reseaux; World Agroforestry Centre: Nairobi, Kenya, 2016.

23. Guissou, K.M.L.; Kristiansen, T.; Lykke, A.M. Local perceptions of food plants in eastern Burkina Faso. Ethnobot. Res. Appl. 2015, 14, 199-209. [CrossRef]

24. Ngadze, R.T. Value Addition of Southern African Monkey Orange (Strychnos spp.): Composition, Utilization and Quality. Ph.D. Thesis, Wageningen University, Wageningen, The Netherlands, October 2018.

25. Shai, K.N.; Ncama, K.; Ndhlovu, P.T.; Struwig, M.; Aremu, A.O. An exploratory study on the diverse uses and benefits of locally-sourced fruit species in three villages of Mpumalanga Province, South Africa. Foods 2020, 9, 1581. [CrossRef] [PubMed]

26. Sitrit, Y.; Loison, S.; Ninio, R.; Dishon, E.; Bar, E.; Lewinsohn, A.E.; Mizrahi, Y. Characterization of monkey orange (Strychnos spinosa Lam.), a potential new crop for arid regions. J. Agric. Food Chem. 2003, 51, 6256-6260. [CrossRef]

27. Avakoudjo, H.G.G.; Hounkpèvi, A.; Idohou, R.; Koné, M.W.; Assogbadjo, A.E. Local knowledge, uses, and factors determining the use of Strychnos spinosa organs in Benin (West Africa). Econ. Bot. 2020, 74, 15-31. [CrossRef] 
28. Thiombiano, D.N.E.; Lamien, N.; Castro-Euler, A.M.; Vinceti, B.; Agundez, D.; Boussim, I.J. Local communities demand for food tree species and the potentialities of their landscapes in two ecological zones of Burkina Faso. Open J. For. 2013, $03,79-87$. [CrossRef]

29. Omotayo, A.O.; Ijatuyi, E.J.; Ogunniyi, A.I.; Aremu, A.O. Exploring the resource value of Transvaal red milk wood (Mimusops zeyheri) for food security and sustainability: An appraisal of existing evidence. Plants 2020, 9, 1486. [CrossRef]

30. White, R.A., III; Chan, A.M.; Gavelis, G.S.; Leander, B.S.; Brady, A.L.; Slater, G.F.; Lim, D.S.S.; Suttle, C.A. Metagenomic analysis suggests modern freshwater microbialites harbor a distinct core microbial community. Front. Microbiol. 2016, 6, 1531. [CrossRef]

31. Nitcheu Ngemakwe, P.N.; Remize, F.; Thaoge, M.; Sivakumar, D. Phytochemical and nutritional properties of underutilised fruits in the southern African region. S. Afr. J. Bot. 2017, 113, 137-149. [CrossRef]

32. Van Wyk, B.-E.; Gericke, N. People's Plants: A Guide to Useful Plants of Southern Africa; Briza Publications: Pretoria, South Africa, 2000.

33. Rodrigues, S.; de Brito, E.S.; de Oliveira Silva, E. Maboque/Monkey Orange-Strychnos spinosa. In Exotic Fruits; Rodrigues, S., de Oliveira Silva, E., de Brito, E.S., Eds.; Elsevier: Amsterdam, The Netherlands, 2018; pp. 293-296.

34. Van Wyk, B. Field Guide to Trees of Southern Africa; Penguin Random House South Africa: Cape Town, South Africa, 2013.

35. Mizrahi, Y.; Nerd, A.; Sitrit, Y. New Fruits for Arid Climates. In Trends in New Crops and New Uses; ASHS Press: Alexandria, VA, USA, 2002; pp. 378-384.

36. Amarteifio, J.O.; Mosase, M.O. The chemical composition of selected indigenous fruits of Botswana. J. Appl. Sci. Environ. Manag. 2006, 10, 43-47. [CrossRef]

37. Lawal, F.; Bapela, M.J.; Adebayo, S.A.; Nkadimeng, S.M.; Yusuf, A.A.; Malterud, K.E.; McGaw, L.J.; Tshikalange, T.E. Antiinflammatory potential of South African medicinal plants used for the treatment of sexually transmitted infections. S. Afr. J. Bot. 2019, 125, 62-71. [CrossRef]

38. Shajib, M.T.I.; Kawser, M.; Nuruddin Miah, M.; Begum, P.; Bhattacharjee, L.; Hossain, A.; Fomsgaard, I.S.; Islam, S.N. Nutritional composition of minor indigenous fruits: Cheapest nutritional source for the rural people of Bangladesh. Food Chem. 2013, 140, 466-470. [CrossRef] [PubMed]

39. Lockett, C.T.; Calvert, C.C.; Grivetti, L.E. Energy and micronutrient composition of dietary and medicinal wild plants consumed during drought. Study of rural Fulani, Northeastern Nigeria. Int. J. Food Sci. Nutr. 2000, 51, 195-208. [CrossRef] [PubMed]

40. Nile, S.H.; Park, S.W. Edible berries: Bioactive components and their effect on human health. Nutrition 2014, 30, 134-144. [CrossRef] [PubMed]

41. Alothman, M.; Bhat, R.; Karim, A. Effects of radiation processing on phytochemicals and antioxidants in plant produce. Trends Food Sci. Technol. 2009, 20, 201-212. [CrossRef]

42. Hur, S.J.; Lee, S.Y.; Kim, Y.-C.; Choi, I.; Kim, G.-B. Effect of fermentation on the antioxidant activity in plant-based foods. Food Chem. 2014, 160, 346-356. [CrossRef] [PubMed]

43. Shahidi, F.; Ambigaipalan, P. Phenolics and polyphenolics in foods, beverages and spices: Antioxidant activity and health effects-A review. J. Funct. Foods 2015, 18, 820-897. [CrossRef]

44. Alasalvar, C.; Shahidi, F. Composition, phytochemicals, and beneficial health effects of dried fruits: An overview. Dried Fruits Phytochem. Health Eff. 2013, 1-18. [CrossRef]

45. Shofian, N.M.; Hamid, A.A.; Osman, A.; Saari, N.; Anwar, F.; Pak Dek, M.S.; Hairuddin, M.R. Effect of freeze-drying on the antioxidant compounds and antioxidant activity of selected tropical fruits. Int. J. Mol. Sci. 2011, 12, 4678-4692. [CrossRef] [PubMed]

46. Brielmann, H.L.; Setzer, W.N.; Kaufman, P.B.; Kirakosyan, A.; Cseke, L.J. Phytochemicals: The chemical components of plants. In Natural Products from Plants, 2nd ed.; Cseke, L.J., Kirakosyan, A., Kaufman, P.B., Warber, S.L., Duke, J.A., Brielmann, H.L., Eds.; Taylor and Francis Group: Boca Raton, FL, USA, 2006; Volume 2, pp. 1-49.

47. Adinortey, M.B.; Sarfo, J.K.; Adinortey, C.A.; Ofori, E.G.; Kwarteng, J.; Afrifa, J.; Owusu, F.A. Inhibitory effects of Launaea taraxacifolia and Strychnos spinosa leaves extract on an isolated digestive enzyme linked to type -2 -diabetes mellitus. J. Biol. Life Sci. 2018, 9, 52-65. [CrossRef]

48. Garba, A.; Muhammad, A.; Ahmad, K.A. In vitro antitrypanosomal and antioxidant activities of diethyl pthalate from the stem bark of Strychnos spinosa Lam. Int. J. Med. Biosci. 2018, 1, 1-22.

49. Kumar, Y.; Basu, S.; Goswami, D.; Devi, M.; Shivhare, U.S.; Vishwakarma, R.K. Anti-nutritional compounds in pulses: Implications and alleviation methods. Legume Sci. 2021, e111, 1-13. [CrossRef]

50. Ahmad, G.; Muhammad, A.; Ahmad, K.; Gbeminiyi, A. Phytochemical and antimicrobial studies of the root bark extracts of Strychnos spinosa Lam. Bayero J. Pure Appl. Sci. 2020, 12, 161-165. [CrossRef]

51. Ugoh, S.C.; Bejide, O.S. Phytochemical screening and antimicrobial properties of the leaf and stem bark extracts of Strychnos spinosa. Nat. Sci. 2013, 11, 123-128.

52. Nwozo, S.O.; Ajayi, I.A.; Obadare, M. Phytochemical screening and antimicrobial activity of 10 medicinal seeds from Nigeria. Med. Aromat. Plant Sci. Biotechnol. 2010, 73-75. Available online: http://www.globalsciencebooks.info/Online/GSBOnline/ images/2010/MAPSB_4(1)/MAPSB_4(1)73-75o.pdf (accessed on 1 December 2021).

53. Tittikpina, N.K.; Atakpama, W.; Hoekou, Y.; Diop, Y.M.; Batawila, K.; Akapagana, K. Strychnos spinosa Lam: Comprehensive review on its medicinal and nutritional uses. Afr. J. Tradit. Complement. Altern. Med. 2020, 17, 8-28. [CrossRef] 
54. Bille, P.; Shikongo-Nambabi, M.; Cheikhyoussef, A. Value addition and processed products of three indigenous fruits in Namibia. Afr. J. Food Agric. Nutr. Dev. 2013, 13, 7192-7212. [CrossRef]

55. Soetan, K.; Olaiya, C.O.; Oyewole, O.E. The importance of mineral elements for humans, domestic animals and plants-A review. Afr. J. Food Sci. 2010, 4, 200-222.

56. Bello, M.; Falade, O.; Adewusi, S.; Olawore, N. Studies on the chemical compositions and anti-nutrients of some lesser known Nigeria fruits. Afr. J. Biotechnol. 2008, 21, 7.

57. Msonthi, J.; Galeffi, C.; Nicoletti, M.; Messana, I.; Marini-Bettolo, G. Kingiside aglucone, a natural secoiridoid from unripe fruits of Strychnos spinosa. Phytochemistry 1985, 24, 771-772. [CrossRef]

58. Nyahangare, E.T.; Hove, T.; Mvumi, B.M.; Hamudikuw, H.; Belmain, S.R.; Madzimure, J.; Stevenson, P.C. Acute mammalian toxicity of four pesticidal plants. J. Med. Plants Res. 2012, 6, 2674-2680.

59. Rampedi, I.T.; Olivier, J. Traditional beverages derived from wild food plant species in the Vhembe District, Limpopo Province in South Africa. Ecol. Food Nutr. 2013, 52, 203-222. [CrossRef] [PubMed]

60. Mkonda, A.; Akinnifesi, F.; Swai, R.; Kadzere, I.; Kwesiga, F.; Maghembe, J.; Saka, J.; Lungu, S.; Mhango, J. Towards domestication of 'wild orange' Strychnos cocculoides in Southern Africa: A synthesis of research and development efforts. In Proceedings of the Regional Agroforestry Conference on Agroforestry Impacts on Livelihoods in Southern Africa: Putting research into Practice, Warmbaths, South Africa, 20-24 May 2002; World Agroforestry Centre (ICRAF): Nairobi, Kenya, 2002; pp. 67-76.

61. Ruffo, C.; Birnie, A.; Tengnas, B. Edible Wild Plants of Tanzania (Volume 27). Regional Land Management Unit/Sida. Available online: http:/ / apps.worldagroforestry.org/downloads/Publications/PDFS/B11913.pdf (accessed on 1 December 2021).

62. Saka, J.; Swai, R.; Mkonda, A.; Schomburg, A.; Kwesiga, F.; Akinnifesi, F. Processing and utilisation of indigenous fruits of the miombo in southern Africa. In Proceedings of the Agroforestry Impacts on Livelihoods in Southern Africa: Putting Research into Practice, Warmbaths, South Africa; 2002; pp. 20-24. Available online: https://www.worldagroforestry.org/publication/ processing-and-utilisation-indigenous-fruits-miombo-southern-africa (accessed on 1 December 2021).

63. Chong, C.H.; Law, C.L.; Figiel, A.; Wojdyło, A.; Oziembłowski, M. Colour, phenolic content and antioxidant capacity of some fruits dehydrated by a combination of different methods. Food Chem. 2013, 141, 3889-3896. [CrossRef] [PubMed]

64. Shackleton, C.; Dzerefos, C.; Shackleton, S.; Mathabela, F. The use of and trade in indigenous edible fruits in the Bushbuckridge savanna region, South Africa. Ecol. Food Nutr. 2000, 39, 225-245. [CrossRef]

65. Malaisse, F.; Parent, G. Edible wild vegetable products in the Zambezian woodland area: A nutritional and ecological approach. Ecol. Food Nutr. 1985, 18, 43-82. [CrossRef]

66. Pátkai, G. Fruit and Fruit Products as Ingredients. In Handbook of Fruits and Fruit Processing; Wiley: California, CA, USA, 2012; pp. 263-275. [CrossRef]

67. Nicoli, M.; Anese, M.; Parpinel, M. Influence of processing on the antioxidant properties of fruit and vegetables. Trends Food Sci. Technol. 1999, 10, 94-100. [CrossRef]

68. Legwaila, G.; Mojeremane, W.; Madisa, M.; Mmolotsi, R.; Rampart, M. Potential of traditional food plants in rural household food security in Botswana. J. Hortic. For. 2011, 3, 171-177.

69. Ham, C.; Akinnifesi, F.K.; Franzel, S.; Jordaan, D.; Hansmann, C.; Ajayi, O.; De Kock, C. Opportunities for Commercialization and Enterprise Development of Indigenous Fruits in Southern Africa. In Indigenous Fruit Trees in the Tropics: Domestication, Utilization and Commercialization; CABI: Wallingford, UK, 2008; pp. 254-272.

70. Akinnifesi, F.; Ajayi, O.; Sileshi, G.; Kadzere, I.; Akinnifesi, A.I. Domesticating and Commercializing Indigenous Fruit and Nut Tree Crops for Food Security and Income Generation in Sub-Saharan Africa. Available online: https://www.worldagroforestry. org/publication/domesticating-and-commercializing-indigenous-fruit-and-nut-tree-crops-food-security-and (accessed on 1 December 2021).

71. Thiong'O, M.; Kingori, S.; Jaenicke, H. The taste of the wild: Variation in the nutritional quality of marula fruits and opportunities for domestication. In Proceedings of the International Symposium on Tropical and Subtropi-cal Fruits 575, Cairns, Australia, 25 November-1 December 2000; pp. 237-244. [CrossRef]

72. Jackson, J.C.; Duodu, K.G.; Holse, M.; de Faria, M.D.L.; Jordaan, D.; Chingwaru, W.; Hansen, A.; Cencic, A.; Kandawa-Schultz, M.; Mpotokwane, S.M.; et al. The Morama Bean (Tylosema Esculentum): A Potential Crop for Southern Africa. In Advances in Food and Nutrition Research; Elsevier: Amsterdam, The Netherlands, 2010; Volume 61, pp. 187-246. 